\title{
3 Research Square

\section{Mitochondrial composition of and diffusion limiting factors of three social wasp genera Polistes, Ropalidia, and Parapolybia (Hymenoptera: Vespidae)}

Li luo

Chongqing Normal University

Pan Huang

Chongqing Normal University

Bin Chen

Chongqing Normal University

Tingjing Li ( $\square$ ltjing1979@hotmail.com )

Chongqing Normal University https://orcid.org/0000-0001-7175-2697

Research article

Keywords: Mitochondrial genome, Geographic distribution, Polistinae, Divergence time

Posted Date: February 12th, 2021

DOI: https://doi.org/10.21203/rs.3.rs-224579/v1

License: (c) (i) This work is licensed under a Creative Commons Attribution 4.0 International License.

Read Full License 


\section{Abstract \\ Background}

Social wasps Polistes, Ropalidia, and Parapolybia, belonging to the subfamily Polistinae, have obviously different distribution patterns, yet the factors leading to this difference remain unknown.

\section{Results}

In this study, mitochondrial genomes (mitogenomes) of 21 species of these three wasp genera were used to phylogenetic analyses, including 17 newly sequenced ones. It is revealed that both evolutionary selection pressure of protein-coding genes (PCGs) and gene rearrangement events are related to the corresponding distribution patterns. In addition, our fossil-calibrated divergence time estimation suggests the diversification of Polistes was in the Late Cretaceous ( 69 million years ago, Ma), and that of Ropalidia and Parapolybia occurred in the Tertiary ( $61 \mathrm{Ma})$. In view of the divergence time and the history of continental drifts, we speculate that Polistes may spread from Africa to South America via the Atlantic Ocean rather than from Asia to South America. On the other hand, combining divergence time and climate changes of both past and the present-day, it is inferred that Quaternary Ice Ages and temperature could be limitation factors in their present distribution patterns.

\section{Conclusions}

There are obvious differences in the mitochondrial composition of Polistes, Ropalidia, and Parapolybia with different distribution ranges. According to the reconstructed time-calibrated framework, we found that the climate and the continental drifts are diffusion limiting factors of the three genera.

\section{Background}

The subfamily Polistinae (Hymenoptera: Vespidae), including more than 950 species of 26 genera and 4 tribes, are social wasps with wide distributions, playing a significant role in the community level and biological control [1-3]. Among the subfamily, Polistes Latreille, 1802 is a cosmopolitan and the largest genus with about 300 species [4, 5]. Ropalidia Guérin-Méneville, 1831, the third largest genus with more than 200 species, is distributed in a greater part of the Old World with a tropical or subtropical climate [6, 7]. Parapolybia de Saussure, 1854, including 13 species, is a small genus and with a much narrower distribution than Ropalidia [8]. Meanwhile, only these three genera in the subfamily Polistinae are distributed in China, also with obviously different distribution patterns that Polistes is widespread, whereas both Ropalidia and Parapolybia are mostly distributed to south of the Qinling Mountains-Huai River (QH) line $\left(104^{\circ} 15^{\prime}-120^{\circ} 21^{\prime} \mathrm{E}, 32^{\circ} 05^{\prime}-34^{\circ} 18^{\prime} \mathrm{N}\right)$. Factors causing their difference of distributions in these three genera are still unknown. 
There are many factors that influence the geographical distribution pattern of a species, such as the origin and evolutionary events, the movements of continental plates, the climate of species habitat, the vicissitudes of plant communities, and human activities [3, 9]. Combined with fossil evidence and distribution data of a species, phylogenetic analyses could infer the origin time, evolutionary history, ancestral distribution areas, and the formation history of the present distribution pattern of this species [10]. Mitochondrial genomes (mitogenomes) harbor characteristics of low levels of sequence recombination, short coalescent time, and generally rapid evolutionary rates in both vertebrates and invertebrates; therefore, phylogenetic trees constructed on mitogenomic sequences are always employed to solve the confusions in the origin time, evolutionary history, and distribution pattern [11, 12]. However, the phylogenetic analyses of Polistes, Ropalidia, and Parapolybia have never been studied using whole mitogenome data.

In this study, to explore the origin time of Polistes, Ropalidia, and Parapolybia, as well as to elucidate the factors that contribute to their present distribution patterns, mitogenomes of 17 species belonging to Polistes, Parapolybia, and Ropalidia were sequenced. The gene orders in mitogenomes of the three genera were systematically compared with that in the putative ancestral of Hymenoptera to find the structure and composition which might be related to the distribution patterns [13-15]. And these data, in combination with two previously reported mitogenomes of Polisties and one of Parapolybia [16-17]. were used to reconstruct phylogenetic trees and estimate origin time. Furthermore, based on the origin time and current distributions, it was analyzed that the vicissitudes of both continental plates and global climates might influence the diversities and distribution patterns of these genera.

On the other hand, the early classifications of both Ropalidia and Parapolybia have undergone relatively extensive transfers as follows, respectively. Ropalidia Guérin-Méneville, 1831 was classified to Ropalidiinae and Parapolybia to Epiponinae [18]. Then, Richards classified Ropalidia to Ropallidiini and Parapolybia to Polybiidae [19]. Li classified Polistes, Ropalidia, and Parapolybia to different families, namely Polistidae, Ropalidiidae, and Polybiidae, respectively [20]. Hereafter, Carpenter divided Polistinae into four tribes in the light of morphology: Epiponini, Mischocyttarini, Polistini, and Ropalidiini; both Parapolybia and Ropalidia belonged to the tribe Ropalidiini, and Polistes to Polistini [4, 21]. Subsequently, the phylogeny of Polistinae using morphological and behavioral characteristics, as well as partial mitogenomic sequences and nuclear markers (CO1, 12S, 16S, 28S, $H 3$, and $E F 1-a)$ was investigated, the result of which supported that Polistinae consisted of four tribes [22]. As long as sequence data are available, there has been constant debates about which data can yield the most accurate result when the topologies obtained from different data sets conflict [23]. Whereas, the mass applications of whole mitogenome data provide great potential for resolving the phylogeny and biogeography which cannot be solved by one or two mitogenomic sequences or nuclear markers [24]. By the way, the classifications of Polistes, Ropalidia, and Parapolybia were further clarified with the application of whole mitogenome data in this study.

\section{Materials And Methods}




\subsection{Sample collection and DNA extraction}

A total of 17 species of these three genera were selected for whole mitogenome sequencing (Table. S1). All the specimens were stored in $95 \%$ ethanol prior at $-20^{\circ} \mathrm{C}$ in Chongqing Normal University (CQNU). Total DNA was extracted from the muscle tissues of thorax using the DNeasy DNA Extraction kit (QIAGEN Shanghai, China). The concentration of double-stranded DNA (dsDNA) in extraction was assayed on a Qubit fluorometer using a dsDNA high-sensitivity kit (Invitrogen Shanghai, China).

\subsection{Sequence assembling and analyses}

The genomic DNA from each sample was pooled and quantified to be $5.0 \mu \mathrm{g}$, and the Illumina TruSeq library was constructed from these DNA, of which the average size of inserted fragment was $480 \mathrm{bp}$. The library was sequenced on the Illumina Hiseq 2500 platform at Berry Genomics, Beijing; 6 Gb clean data was obtained for each species. These reads were used in de novo assembly with IDBA-UD after getting rid of adapters, unpaired, and lower quality reads [25]. The parameters used for assemblies with IDBA-UD were a similarity threshold of $98 \%$ and minimum and maximum $\mathrm{K}$ values of 80 and $240 \mathrm{bp}$. Using primers designed by Simon [26], the COX1 and srRNA used as targeting sequences were amplified by standard PCR reactions, which were used to confirm if the mitogenomes was assembled from the pooled sequencing files. The BLASTn search was used to identify the mitogenomes sequences based on the reference of bait sequences [27].

PCGs, tRNAs, rRNAs, and control regions were identified by searching homologous sequences against the publicly available Vespidae mitogenomes using ClustalX 1.8 [28]. Nucleotide composition was calculated by using MEGA 6.0 [29]. CG View was used to circularize the mitogenomic sequences [30]. The software package DnaSP 5.0 [31] was used to calculate the non-synonymous $(K a)$ and synonymous $(K S)$ substitution ratio $(K a / K s)$ for each sequenced mitogenome. To test significance of $K a / K s$ and $A+T$ content among Polistes, Ropalidia, and Parapolybia, the one-way analysis of variance (ANOVA) was used as implemented in $\mathrm{R}$ core packages with default settings [32]. Gene rearrangement histories of these three wasp genera were reconstructed by using TreeREx 1.85 [33].

\subsection{Phylogenetic analyses}

In the phylogenetic analyses, 17 whole mitogenome sequences generated in this study and 18 from previous researches were included, representing the four subfamilies of Vespidae (Table. S2). The mitogenomic sequences of Apis cerana (Apidae), Megachile sculpturalis (Megachilidae), and Philanthus triangulum (Crabronidae) were used as outgroups. Multiple alignments were aligned individually by codon-optimized using the L-INS-i strategy with MAFFT algorithm [34], and ambiguous alignment regions were trimmed from the sequences using Gblocks program in TranslatorX [35, 36]. Alignments of individual genes were concatenated as two datasets: 1) PCGR: 13 PCGs and 2 rRNA; 2) AA: amino acid sequences of the 13 PCGs. The two datasets were used in our phylogenetic analyses. The Bayesian inference (BI) with MrBayes v3.1.2 [37] was performed for phylogenetic inference. The BI tree was constructed with the average deviation of split frequencies below 0.01 , approximately $1,000,000$ 
generations were conducted for the matrix, and each set was sampled every 1,000 generations with a burn-in of $25 \%$. Maximum likelihood (ML) analysis was performed by PHYML [38] online web server with default parameters and the node support values were evaluated via a bootstrap test with 100 replicates.

\subsection{Divergence time estimation}

The divergence time was estimated using BEAST v.2.5.0 [39]. The GTR + I + G nucleotide substitution model and the speciation Yule model were selected as the tree priors with the uncorrelated lognormal relaxed molecular clock model. Two independent Markov Chain Monte Carlo (MCMC) runs, each had a chain length of 1,000,000 generations with sampling every 1,000 generations and a first $25 \%$ burn-in, were performed to estimate the divergence time. Paleovespa menatensis of Vespinae (64 - 60 million years ago, Ma) and Symmorphus senex of Eumeninae (94 - $90 \mathrm{Ma}$ ) were selected for calibration [40, 41].

\section{Results}

\subsection{The latest distributions of the three genera}

The distributions of the three genera based on the latest statistics of species checklists $[4,5,7,42-53]$ were newly sorted out and located on the world map using Bigemap (http://www.bigemap.com) (Fig. 1). The northernmost distributions of Polistes, Ropalidia, and Parapolybia are Victoria of Canada $\left(123^{\circ} 22^{\prime} \mathrm{W}\right.$, $\left.48^{\circ} 25^{\prime} \mathrm{N}\right)$, Pakistan $\left(71^{\circ} 27^{\prime} \mathrm{E}, 29^{\circ} 79^{\prime} \mathrm{N}\right)$, and Turkey $\left(39^{\circ} 46^{\prime} \mathrm{E}, 34^{\circ} 27^{\prime} \mathrm{N}\right)$, respectively. While the southernmost distributions of these three genera are Río Negro of South Africa ( $\left.63^{\circ} 03^{\prime} \mathrm{W}, 40^{\circ} 82^{\prime} \mathrm{S}\right)$, Western Cape of South Africa $\left(19^{\circ} 82^{\prime} \mathrm{E}, 33^{\circ} 37^{\prime} \mathrm{S}\right)$, and Timor Island $\left(124^{\circ} 05^{\prime} \mathrm{E}, 9^{\circ} 62^{\prime} \mathrm{S}\right)$, respectively.

\subsection{Mitogenomic composition of the three genera}

In this study, for the first time, 17 whole mitogenome sequencing on Polistes, Ropalidia, and Parapolybia was preformed, which greatly enriches the mitogenome data of Vespaidae. Most newly sequenced mitogenomes contain 37 genes (Fig. S1), including 13 PCGs, 22 tRNA genes, and two rRNA genes, as well as a control region, which has been conformed in most metazoan animals [54]. However, several mitogenomes are short of one or two genes. For example, Ropalidoa sp. lacks $\operatorname{trn} Y$; Ro. magnanima lacks trnQ (Fig. S2). Among these three genera, the A + T content of Polistes is the highest, and the GC-skew and AT-skew are considerably variable in Ropalidia (Fig. S3). Their nucleotide composition is significantly biased toward adenine and thymine, with an $\mathrm{A}+\mathrm{T}$ content more than $80 \%$ and the order of their $\mathrm{A}+\mathrm{T}$ content is Polistes $>$ Ropalidia > Parapolybia. And the result of ANOVA suggests that there is a significant difference $(P=0.0020)$ among the $A+T$ content of the three wasp genera (Fig. 2b). Hua et al. suggested that the variations of GC-skew and AT-skew are related to species biodiversity of geographical distributions with different widths [55]. The most widely distributed genus is Polistes among the three; however, it does not show the most significant variation in GC-skew or AT-skew, which may be due to the fact that these three genera have undergone different adaptation or selection processes. 
The results of $K a / K s$ values of the three genera for 13 PCGs indicate that the order of $K a / K s$ values is Polistes > Ropalidia > Parapolybia for all PCGs but ND6, COX2 and CYTB (Fig. 2a). Meanwhile, the average $\mathrm{Ka} / \mathrm{Ks}$ value of total PCGs in Polistes is the highest among the three wasp genera and that of Parapolybia is the lowest. Significant difference $(P=0.0023)$ were observed among the $K a / K s$ values of the three wasp genera (Fig. 2c). It has been reported that the duration and magnitude of $\mathrm{Ka} / \mathrm{Ks}$ elevation depend on the effective population size [56]. Considering the fact that the distribution of Polistes is the widest while that of Parapolybia is the narrowest, we speculate that the selective pressure on these three genera may be related to species biodiversity of geographical distributions with different widths.

\subsection{Gene arrangements}

Mitogenomes of insects are usually stable in structure; gene orders are relatively conservative, and recombination events rarely occur in the evolutionary history of insects [57]. However, the number of mitochondrial gene rearrangements in the Hymenopteran lineages was clearly toward an increase [58]. Our results indicate that at least six gene rearrangement events occurred. As shown in Fig. 3, the arrangements of 13 PCGs and 2 rRNA genes in mitogenomes of the three genera are identical to that of the putative ancestral Hymenoptera. A gene rearrangement event is common in Ropalidia and Parapolybia mitogenomes, that is, the translocation of $\operatorname{trn} Y$ from the location between $\operatorname{trn} C$ and $\operatorname{cox} 1$ to the upstream of $\operatorname{trn} /(\mathrm{T} 1)$; the recombination events seem to be the most plausible explanation for this translocation. In addition, the swap of positions between nad 1 and $t r n L 1$ resulted in a rearranged gene order of trnS2-trnL1-nad1 in Parapolybia mitogenomes, which is also found in Polistes and can be explained by tandem-duplication-random-loss (TDRL) models (TDRL II and TDRL III). Furthermore, it was also identified that intergenic spacers (IGSs) between $\operatorname{trn} S 2$ and $\operatorname{trn} L 1$, and between nad 1 and $r r n L$ in both Parapolybia and Polistes, corresponded to random gene losses, providing evidence supporting gene duplication and deletion events in gene rearrangements (TDRL II and TDRL III). However, in Ropalidia, the swap of positions between trnS2 and trnL 1 led to a rearranged gene order of trnL 1-nad1-trnS (TDRL I) and there are also two IGSs between trnS2 and cytb, and between nad1 and $r r n L$. Moreover, three more rearrangement events were found in Polistes: trnD from the downstream of trnK to its upstream in Po. jokahamae (TDRL IV); trnQ from the downstream of trn/ to its upstream in Po. snelleni, Po. sagittarius, and Po. rothneyi iwatai, $\operatorname{trn} Y$ translocated from the location between $\operatorname{trn} C$ and $\operatorname{cox} 1$ to the upstream of $t r n I$ (T2) in six sequenced species. The IGSs between $\operatorname{trn} Q$ and $\operatorname{trn} Y$, trnY and $t r n l$, and $t r n /$ and $t r n M$ in $P o$. snelleni, Po. Sagittarius, and Po. rothneyi iwatai corresponded to random gene losses and genes separated by the translocation of $\operatorname{trn} Y$, providing evidences that support gene duplication, deletion, and recombination events in gene rearrangements (Fig. S4). Our results indicate that more than three rearrangement events occurred in Polistes and two in Ropalidia and Parapolybia, which might be explained by the fact that the wider the species geographical distribution is the richer the environment diversity is. This further resulted in an increase in the selective pressure, which might lead to the occurrence of gene rearrangements.

\subsection{Phylogenetic relationships and divergence time estimation}


In this study, the PCGR and AA datasets were used to individually reconstruct phylogeny of Polistes, Parapolybia, and Ropalidia. Using both $\mathrm{BI}$ and $\mathrm{ML}$ methods, four phylogenetic trees were generated, and no significant difference was observed in either $\mathrm{Bl}$ or $\mathrm{ML}$ tree between the two datasets. The monophyly of each genus is well supported in all trees with bootstrap values greater than 80 and posterior probabilities of at least 0.89 (Fig. S5). In Vespidae, the phylogenetic relationship Stenogastrinae + (Eumeninae $+($ Vespinae + Polistinae) $)$ is supported by transcriptomic and other molecular studies [59] . Polistinae forms a sister relationship with Vespinae, which is supported by previous studies on both morphological characteristics and molecular data [22, 60, 61]. In addition, within the subfamily Polistinae, the relationship (Ropalidia + Parapolybia) is concordant with previous morphological analysis of Polistinae that the two genera belong to one tribe $[4,21]$.

Given that the topology of phylogenetic trees between the two datasets was similar, the PCGR dataset was used to estimate divergence time as it had higher node support values in initial phylogenetic assessment. The result (Fig. 4) indicates that the subfamily Polistinae evolved over a period of $75 \mathrm{Ma}$, which is consistent with an earlier report [62]. Meanwhile the genus Polistes diverged at around $69 \mathrm{Ma}$, Parapolybia + Ropalidia were separated from the subfamily Polistinae at around $61 \mathrm{Ma}$, and the origin of Parapolybia was later than Ropalidia.

\section{Discussion}

\subsection{Effects of continental drifts on the three genera}

It is generally recognized that continental drifts play a key role in the origin and evolution of organisms [63]. There is a hypothesis that the subfamily Polistinae probably diverged from other Vespidae at the breakup of Gondwanaland ( $135 \mathrm{Ma}$ ) and their Gondwanian connections were via tropical Africa and tropical South America [22]. However, the divergence time of Polistinae estimated based on whole mitogenome data in this study $(75 \mathrm{Ma})$ is greatly later than the breakup of Gondwanaland, approximately 60 million years (Myr) after the fragmentation of Gondwana. The early notion generally was that Polistes first evolved in the Oriental tropics, whence it dispersed to the rest of the globe, with an invasion of the New World occurring via Beringia [64]. Whereas, some later phylogenetic studies have suggested that Polistes dispersed into the New World from the Old World, and South America was recovered as the ancestral area for all Polistes in the New World $[22,65]$. In the view of how Polistes dispersed from the Old World to the New World, the two aforementioned hypotheses are inconsistent (Fig. 5). In our present study, by tracing the history of plate drifts, it was found that at the estimated origin time of Polistes ( $69 \mathrm{Ma})$, North America had been separated from Laurasia during the Jurassic (208 - $135 \mathrm{Ma}$ ). Even though a narrow land channel was formed through the Bering Strait due to the influence of glaciers in the Pleistocene ( 1.0 Ma), the climate in the Pleistocene period was extremely cold that the exchange of species was heavily prevented between Europe and North America [66]. Meanwhile, at the time Polistes originated, the tropical Gondwana had been broken for $40 \mathrm{Myr}$, and there were no existing uninterrupted land bridges between tropical Africa and South America after $80 \mathrm{Ma}$. Given the fact that the prior 
existence of land connections cannot explain the present distribution of Polistes, the mismatch between the divergence time of Polistes and tectonic fragmentation implies an oceanic dispersal.

The oceanic dispersal of Polistes from the Old World to South America may occur in two routes: transAtlantic Ocean between South America and Africa, and trans-Pacific Ocean between Asia and South America. We compared the possibilities of these two routes. Up to date, South America is separated from Africa by at least 2,600 km of ocean, and the Atlantic Ocean first appeared well after the onset of the Gondwana breakup ( $110 \mathrm{Ma}$ ) [67]. According to rates of motion of the South Atlantic Ocean (22$28 \mathrm{~mm} / \mathrm{a}$ ) based on International Terrestrial Reference Frame 2000 (ITRF2000) [68], we determined that the distance between South America and Africa at 69 Ma was 902-1,148 km, which is consistent with that of Sclater [69]. The study of Ford et al. indicated the shortest distance between Africa and South America was around 1,000 km in a straight line (from present-day Sierra Leone to Paraíba state, in Brazil) at $50 \mathrm{Ma}$, which also supports our estimated distance [70]. Correspondingly, South America is separated from Asia by at least 20,000 km of ocean [71] The Pacific Ocean evolved from Panthalassa in the Late Carboniferous (314-290 Ma), and it had been shrinking owing to the fragmentation of Gondwana, and the expansion of the Indian Ocean and Atlantic Ocean [72], which means South America was separated from Asia by more than $20,000 \mathrm{~km}$ of ocean at $69 \mathrm{Ma}$. Hence, it is easier to understand (more acceptable) that the Polistes may spread to South America via the Atlantic Ocean due to the significantly smaller distance.

On the other hand, trans-ocean migrations may also rely on the presence of volcanic islands and rafting on buoyant vegetation. In the Atlantic Ocean, several islands of considerable size (more than $200 \mathrm{~km}$ in length) persisted along the present-day submerged Rio Grande Rise and Walvis Ridge at $50 \mathrm{Ma}$ and the long set of islands (at least $800 \mathrm{~km}$ in length) had stretched from the Brazilian coast at $20^{\circ} \mathrm{S}$ (at the present-day Martin Van Archipelago) at $50-40 \mathrm{Ma}$ [73]. Likewise, there were also many islands in the Pacific Ocean such as Fijian Islands, Borneo, West Sulawesi, and Hawaii Islands, formed by volcanic eruptions in the Late Cretaceous (100-65 Ma) [74]. Among these islands, the closest one to South America called Adamstown was more than $6,000 \mathrm{~km}$ away, a distance much longer than that between South America and Africa at $69 \mathrm{Ma}$ [75]. Furthermore, animals had more difficulties in crossing ocean barriers than plants, and many animals attached to rafting on buoyant vegetation to trans-ocean [76]. Therefore, the shorter distance between South America and Africa during the origin of Polistes inspired us to think whether Polistes originated in Asia or Africa-the Polistes species may disperse from Africa to South America via the volcanic islands and/or rafting on buoyant vegetation, and finally to North America via the Isthmus of Panama between South and North America.

Ropalidia and Parapolybia are distributed in the Old World, and their divergence time is estimated at $61 \mathrm{Ma}$ in the Palaeocene (65 - $53 \mathrm{Ma}$ ). During this period, Africa collided with Europe, leading to the formation of Alps. In addition, even though Indian and Oceania were separated from the Gondwanaland during the Late Jurassic ( $135 \mathrm{Ma}$ ), Indian also collided with Asia in Southern Tibet in the Eocene (53$36.5 \mathrm{Ma}$ ). Hereafter, all the continents of the Old World except Australia had been connected until the present day [63]. According to the formation history of the Old World, there should be chances that 
Ropalidia and Parapolybia spread among various plates except Australia. There were many islands, such as Philippine Islands and New Guinea, between Australia and the Eurasian subcontinent at $65-53 \mathrm{Ma}$ [66], it is possible that the two genera Ropalidia and Parapolybia spread to Australia through these islands. Our inference is also supported by the result of Saito et al. that the current faunal composition and distribution pattern of Ropalidia in Australia actually originated in New Guinean and migrated via the Cape York Peninsula and further speciated in Australia [77]. In this study, the questions that where Ropalidia and Parapolybia originated and why Parapolybia species are not recorded in Australia remain unanswered, which require further information.

\subsection{Effects of climate changes on the three genera}

Climate changes also have major impacts on terrestrial biodiversity, directly affecting species distribution patterns $[78,79]$. In our study, the last major climate change is traced back to the start of Quaternary Ice Ages (2.6-0.015 Ma) [80], because the current entire northern fauna and flora had been greatly changed during Quaternary Ice Ages when the European ice sheets covered the lands in Europe including Siberia to Mongolia, and the North American ice sheets moved from Canada to the northern United States, where it was extreme cold that many animals and plants had to move to the south $[80,81]$. And the current climate had not been formed until the end of the Pleistocene ( $0.015 \mathrm{Ma})[80,82]$. The last Ice Age ended at the beginning of the Holocene $(0.015 \mathrm{Ma})$, and then the climate in the Holocene (0.015 Ma-present) became warmer, which was similar to the present-day climate [83]. As the climate getting warmer, some animals and plants migrated backward to the north [84]. Currently, there are a few of Polistes and few of both Ropalidia and Parapolybia distributed in the areas covered by ice sheets during Quaternary Ice Ages. Therefore, it may be inferred that Quaternary Ice Ages was a limitation factor in the northernmost distributions of the three genera.

Furthermore, it has been indicated that temperatures are important in defining the scope for intrasexual signaling in social wasps and play a role in maintaining variations in intrasexual traits in the view of sexual selection [85]. The most suitable temperature for social wasps is $25^{\circ} \mathrm{C}$ and the most comfortable relative humidity is $50-70 \%[86,87]$. The average annual climate in Antarctica is $-25^{\circ} \mathrm{C}$ and the highest temperature in the North Pole area is $-8^{\circ} \mathrm{C}$ [88], which may be one of the reasons that the wasps are not distributed there. There is a long winter and short summer in the middle temperate zone $\left(40^{\circ} \mathrm{N}\right.$ to $50^{\circ} \mathrm{N}$, $40^{\circ} \mathrm{S}$ to $50^{\circ} \mathrm{S}$ ) [89], including Mongolia Plateau, most of Northeast China, and North Canada, where annual temperatures vary greatly and the living animals are mostly homoiothermic animals [90]. In view of the influence of the temperature, most of wasps have the habit of overwintering [89], and long-term exposure to low temperatures would result in failure of wasps to overwinter [90], so there are relatively fewer Polistes and neither of Ropalidia and Parapolybia distributed in the middle temperate zone. To the contrary, in the subtropics $\left(23^{\circ} 26^{\prime} \mathrm{N}\right.$ to $40^{\circ} \mathrm{N}, 23^{\circ} 26^{\prime} \mathrm{S}$ to $\left.40^{\circ} \mathrm{S}\right)$ and tropics $\left(23^{\circ} 26^{\prime} \mathrm{S}\right.$ to $\left.23^{\circ} 26^{\prime} \mathrm{N}\right)$ [91], there is a small difference among the annual temperatures (above zero in winter), and plentiful precipitation and vegetation can support sufficient foods $[92,93]$. Therefore, modern climate pattern also plays an important role in these genera distributions, as most of these wasps are coincidentally distributed in tropical and subtropical zones. 
Meanwhile, the fact that Polistes, Ropalidia, and Parapolybia are abundant to the south of QH line in China can also be explained by our finding that the climate pattern influences species distributions. QH line is situated across the middle temperate, tropical and subtropical zones and is the north-south geographical, climatic, and demographic watershed of China. And it also serves as the boundary of the middle temperate and subtropical zones, and the boundary of the Palearctic and Oriental regions [94].

\section{Conclusions}

According to the mitogenomic composition of the three genera of Polistes, Ropalidia and Parapolybia, the variation in GC-skew or AT-skew is not positively corrected with geographical distributions, yet the $\mathrm{Ka} / \mathrm{Ks}$ value shows the positive relationship with distribution range. In addition, gene rearrangement events are common in the three genera, and the more the number of the genus species is and the wider its geographical distribution is, the higher the probability of gene rearrangement occurrence is. In summary, variations of their mitogenomes may be accompanied by differences of the geographic distributions.

The monophyly of the genus Polistes is consistently supported with bootstrap values (BS) 100 and posterior probabilities (PP) 1, and a monophyletic Ropalidiini: (Ropalidia + Parapolybia) is concordant with previous morphological analysis of Polistinae. And then the divergence times demonstrate Polistes (at around $69 \mathrm{Ma}$ ) was diverged earlier than Ropalidia and Parapolybia (at around $61 \mathrm{Ma}$ ). Combining the history of continental drifts and their divergence time, continental drift is inferred to be one limiting factor in the current distributions of these three wasps. Hereafter, it is a more likely scenario that Polistes spread from the Old World to the New World by the transatlantic diffusion route rather than the hypothetical transpacific one. Meanwhile, Polistes and Ropalidia are considered to spread from Southeast Asia to Australia through New Guinea and other islands. Referring to the coverage of the ice sheet during Quaternary Ice Ages, we deduce that Quaternary Ice Ages is another limitation factor, especially which restricted the northernmost distributions of these three genera. Of course, it is confirmed that modern climate pattern plays a decisive role in the current distributions of these genera. Other potential factors such as human activities, plant communities and so on are needed to further explore.

\section{Declarations}

\section{Ethics approval and consent to participate}

Not applicable.

\section{Consent for publication}

Not applicable.

Data accessibility: Mitochondrial genome sequences are accessible on GenBank and accession numbers were in electronic supplementary material of table $S 2$. 
Authors' contributions: Li Luo completed all the analysis and wrote the manuscript. Fossil-calibrated divergence estimation was generated with the help of Pan Huang. Bin Chen gave important comments on both this study and manuscript. Tingjing $\mathrm{Li}$ is responsible for the implementation of the entire project. All authors approved the final version of the manuscript and agree to be accountable for all aspects of the work.

\section{Declaration of Competing Interest}

The authors declare no conflict of interest.

\section{Acknowledgements}

We thank Dr. Fan Song (College of Plant Protection, China Agricultural University, Beijing, China) for providing some important comments on our study.

\section{Funding}

This study was funded by the National Natural Science Foundation of China (Nos: 31772490, 31372247, 31000976), Young Talent Incubation Programme of Chongqing Normal University (14CSDG07).

\section{References}

[1] Richter MR. Social wasp (Hymenoptera: Vespidae) foraging behavior. Annual Review of Entomology. 2000; doi:10.1146/annurev.ento.45.1.121.

[2] Rusina LY. Principles of organization of Polistinae (Hymenoptera, Vespidae) Population. Entomological Review. 2015; doi:10.1134/S0013873815080102.

[3] Ferreira JVA, Storck-Tonon D, da Silva RJ, Somavilla A, Pereira MNJB, da Silva DJ. Effect of habitat amount and complexity on social wasps (Vespidae: Polistinae): implications for biological control. Journal of Insect Conservation. 2020; doi:10.1007/s10841-020-00221-7.

[4] Carpenter JM. Distributional checklist of species of the genus Polistes (Hymenoptera: Vespidae; Polistinae, Polistini). American Museum of Natural History. 1996a; doi:10.1016/S0020-1383(99)00074-1.

[5] Kojima J. Checklist and/or catalog of social wasps. 2006a;

http://www.ipc.ibaraki.ac.jp/ jkrte/wasp/list.html.

[6] Carpenter JM and Kojima J. Catalog of Species in the Polistine tribe Ropalidiini (Hymenoptera: Vespidae). The American Museum of Natural History Central Park West. 1997; http://hdl.handle.net/2246/3597.

[7] Kojima J. Web page catalog of species in the Polistine Tribe Ropalidiini (Hymenoptera:Vespidae). 2006b; http://www.jpc.ibaraki.ac.jp/ jkrte/wasp/ropa/top.html. 
[8] Saito F, Nguyen LTP, Kojima JI. Review of the paper wasps of the Parapolybia indica species-group (Hymenoptera: Vespidae, Polistinae) in eastern parts of Asia. Zootaxa. 2015;

doi:10.11646/zootaxa.3947.2.5.

[9] Gaynor ML, Fu CN, Gao LM, Lu LM, Soltis DE, Soltis PS. Biogeography and ecological niche evolution in Diapensiaceae inferred from phylogenetic analysis. Journal of Systematics and Evolution. 2020. Doi:10.1111/jse.12646.

[10] Johnson AJ, McKenna DD, Jordal BH, Cognato Al, Smith SM, Lemmon AR, Moriarty Lemmon EL, Jiri Hulcr. Phylogenomics clarifies repeated evolutionary origins of inbreeding and fungus farming in bark beetles (Curculionidae, Scolytinae). Molecular Phylogenetics and Evolution. 2018; doi:

10.1016/jympev.2018.05.028.

[11] Heraty J, Ronquist F, Carpenter JM. Evolution of the hymenopteran megaradiation. Molecular Phylogenetics and Evolution. 2011; doi:10.1016/jympev.2011.04.003.

[12] Wang Y, Cao JJ and Li WH. Complete mitochondrial genome of Suwallia teleckojensis (Plecoptera: Chloroperlidae) and implications for the higher phylogeny of stoneflies. International Journal of Molecular Sciences. 2018; doi:10.3390/ijms19030680.

[13] Cameron SL, Dowton M, Castro LR. Mitochondrial genome organization and phylogeny of two vespid wasps. Genome. 2008; doi:10.1139/G08-066.

[14] Cameron SL. Insect mitochondrial genomics: implications for evolution and phylogeny. Annual Review of Entomology. 2014; doi:10.1146/annurev-ento-011613-162007.

[15] Song SN, Tang P, Wei SJ, Chen XX. Comparative and phylogenetic analysis of the mitochondrial genomes in basal hymenopterans. Scientific Reports. 2016; doi:10.1038/srep20972.

[16] Castro L R and Dowton M. The position of the Hymenoptera within the Holometabola as inferred from the mitochondrial genome of Perga condei (Hymenoptera: Symphyta: Pergidae). Molecular Phylogenetics Evolution. 2005; doi:10.1016/jympev.2004.11.005.

[17] Peng Y, Chen B, Li TJ. Sequencing and analysis of the complete mitochondrial genome of Parapolybia crocea (Hymenoptera: Vespidae). Acta Entomologica Sinica. 2017; doi:10.16380/j.kcxb.2017.04.011.

[18] Bequaert JC. A revision of the Vespidae of the Belgian Congo based on the collection of the American Museum Congo Expedition, with a list of Ethiopian diplopterous wasps. Bulletin of the American Museum of Natural History. 1918; doi:10.1111/j.1469-79981878.tb08032.x.

[19] Richards OW. A revisional study of the masarid wasps (Hymenoptera, Vespidae). British Museum (Natural History), 1962; vii [+ i] + 294. 
[20] Li TS. Economic insect fauna of China. Fasc. 30. Hymenoptera: Vespoidea. Science Press, Beijing, 1985;159 pp.

[21] Carpenter JM. Phylogeny and biogeography of Polistes. Turillazzi, S., West-Eberhard. M.J. (Eds.), Natural History and Evolution of Paper-Wasps, Oxford University Press. 1996b;18-57.

[22] Carpenter JM. The phylogenetic relationships and natural classification of the Vespoidea (Hymenoptera). Systematic Entomology. 1982; doi:10.1111/j.1365-31131982.tb00124.x.

[23] Carpenter JM, Kojima J, Wenze JW. Polybia, paraphyly and polistine phylogeny, American Museum of Natural History. 2000; doi:10.1206/0003-0082(2000)2982.0.CO;2.

[24] Du ZY, Hasegawa K, Cooley JR, Simon C, Yoshimura J, Cai WZ, Sota TJ, Li H. Mitochondrial genomics reveals shared phylogeographic patterns and demographic history among three periodical cicada species groups. Molecular Biology and Evolution. 2019; doi:10.1093/molbev/msz051.

[25] Peng Y, Leung HCM, Yiu SM, Chin FYL. IBDA-UD: a de novo assembler for single-cell and metagenomic sequencing data with highly uneven depth. Bioinformatics. 2012; 28:1420-1428.

[26] Simon C, Buckley TR, Frati F, Stewart JB, Beckenbach AT. Incorporating molecular evolution into phylogenetic analysis, and a new compilation of conserved polymerase chain reaction primers for animal mitochondrial DNA. Annual Review of Ecology Evolution and Systematics. 2006; doi:10.1146/annurev.ecolsys.37.091305.110018.

[27] Altschup S, Gish W, Miller W, Myers E, Lipman D. Basic local alignment search tool. Journal of Molecular Biology. 1990; 215: 403-410.

[28] Thompson JD, Gibson TJ, Plewniak F, Jeanmougin F, Higgins DG. The CLUSTAL X windows interface: flexible strategies for multiple sequence alignment aided by quality analysis tools. Nucleic Acids Research. 1997; doi:10.1093/nar/25.24.4876.

[29] Tamura K, Stecher G, Peterson D, Filipski A, Kumar S. MEGA6: Molecular evolutionary genetics analysis version 6.0. Molecular Biology and Evolution. 2013; doi:10.1093/molbev/mst197.

[30] Stothard P, Wishart DS. Circular genome visualization and exploration using CGView. Bioinformatics 21, 537-539. (doi:10.1093/bioinformatics/bti054)

[31] Librado P, Rozas J. 2009 DnaSPv5: a software for comprehensive analysis of DNA polymorphism data. Bioinformatics. 2005; doi/10.1093/bioinformatics/btp187

[32] R Core Team, R: A Language and Environment for Statistical Computing, 2015; doi:10.1007/978-3540-74686-7. 
[33] Bernt M, Merkle D, Middendorf M. An algorithm for inferring mitogenome rearrangements in a phylogenetic tree. C.E. Nelson, S. Vialette, (Eds.), Comparative genomics, lecture notes in computer science. 2008; 143-157.

[34] Katoh K, Standley DM. MAFFT multiple sequence alignment software version 7: improvements in performance and usability. Molecular Biology and Evolution. 2013; doi:10.1093/molbev/mst010.

[35] Castresana J. Selection of conserved blocks from multiple alignments for their use in phylogenetic analysis. Molecular Biology and Evolution. 2000; doi: 10.1093/oxfordjournals.molbev.a026334.

[36] Abascal F, Zardoya R, Telford MJ. TranslatorX: multiple alignment of nucleotide sequences guided by amino acid translations. Nucleic Acids Research. 2010; doi:10.1093/nar/gkq291.

[37] Ronquist F, Huelsenbeck JP. MrBayes 3: Bayesian phylogenetic inference under mixed models. Bioinformatics. 2003; doi:10.1093/bioinformatics/btg180.

[38] Guindon S, Dufayard JF, Lefort V, Anisimova M, Hordijk W, Gascue O. New algorithms and methods to estimate maximum-likelihood phylogenies: Assessing the performance of PhyML 3.0. Systematic Biology. 2010; doi:10.1093/sysbio/syq010.

[39] Drummond AJ and Rambaut A. BEAST: Bayesian evolutionary analysis by sampling trees. BMC Evolutionary Biology. 2007; doi:10.1186/1471-2148-7-214.

[40] Nel Auvray F. The oldest Vespinae from the Paleocene of Menat (France) (Hymenoptera: Vespidae). Zootaxa, 2006; doi:10.5281/zenodo.174484.

[41] Carpenter JM. A vespid wasp from New Jersey Cretaceous amber. Grimaldi, D.A. (Ed.), Studies on fossils in amber, with particular reference to the cretaceous of New Jersey, 2000b; 333-337.

[42] Saito F, Kojima JI, Nguyen LTP, Kanuka M. Polistes formosanus Sonan, 1927 (Hymenoptera: Vespidae), a good species supported by both morphological and molecular phylogenetic analyses, and a key social wasp in understanding the historical biogeography of the Nansei Islands. Zoological Science. 2007; doi:10.2108/zsj.24.927.

[43] Dvorak L and Carpenter JM. The first record of the paper wasp Polistessmithii neavei von Schulthess, 1921, from the Middle East (Hymenoptera: Vespidae), with notes on the social wasp fauna of Yemen. Zoology in the Middle East. 2008; 44, 119-120.

[44] Abbasi R, Mashhadikhan M, Abbasi M, Kiabi B. Geometric morphometric study of populations of the social wasp, Polistes dominulus (Christ, 1791) from Zanjan province, north-west Iran. New Zealand Journal of Zoology. 2009; doi: 10.1080/03014220909510138.

[45] Eardley C, Koch F, Wood AR. Polistes dominulus (Christ, 1791) (Hymenoptera: Polistinae: Vespidae) newly recorded from South Africa. African Entomology. 2009; doi:10.4001/003.017.0214. 
[46] Madden AA, Davis MM, Starks PT. First detailed report of brood parasitoidism in the invasive population of the paper wasp Polistes dominulus (Hymenoptera, Vespidae) in North America. Insectes Sociaux. 2010; doi:10.1007/s00040-010-0079-0.

[47] Cranshaw WS, Larsen HJ, Zimmerman RJ. Notes on fruit damage by the European paper wasp, Polistes dominula (Christ) (Hymenoptera: Vespidae). Southwestern Entomologist. 2011; doi:10.3958/059.036.0110.

[48] Nguyen LTP, Kojima J, Saito F. Polistes (Polistella) wasps (Hymenoptera: Vespidae: Polistinae) from mountainous areas of northern Vietnam, with description of five new species. Zootaxa. 2011; doi:10.11646/zootaxa.3060.1.1.

[49] Bagriacik N. Some structural features of nest materials of Polistes nimpha (Christ, 1791) in several ecological conditions (Hymenoptera: Vespidae). Journal of the Entomological Research Society. 2013; 15, $1-7$.

[50] Neumeyer R, Baur H, Guex GD, Praz C. A new species of the paper wasp genus Polistes (Hymenoptera, Vespidae, Polistinae) in Europe revealed by morphometrics and molecular analyses. Zookeys. 2014; doi:10.3897/zookeys.400.6611.

[51] Loope KJ and Carpenter JM. Polistesmajormajor and Polistes apachus (Hymenoptera: Vespidae) in Georgia, USA. Florida Entomologist. 2016; doi:10.1653/024.099.0332.

[52] Selis M. Revision of the genus Polistes Latreille (Hymenoptera: Vespidae: Polistinae) in the Philippine Islands. Zootaxa. 2018a; doi:10.11646/zootaxa.4531.4.3.

[53] Selis M. Description of the first endemic Polistes Latreille, 1802 from Sulawesi (Hymenoptera: Vespidae: Polistinae). Zootaxa. 2018b; doi:10.11646/zootaxa.4508.3.7.

[53] Nguyen LTP. Contribution to the taxonomy of the paper wasp genus Polistes (Polistella) (Hymenoptera: Vespidae: Polistinae) from Vietnam, with description of a new species. Zootaxa. 2020; doi:10.11646/zootaxa.4759.2.7.

[54] Boore JL. Animal mitochondrial genomes. Nucleic Acids Research. 1999; doi:10.1093/nar/27.8.1767.

[55] Hua YQ and Ding YR, Yan ZT, Si FL, Luo QC, Chen B. The complete mitochondrial genome of Anopheles minimus (Diptera: Culicidae) and the phylogenetics of known Anopheles mitogenomes. Insect Science, 2016; doi:10.1111/1744-7917.12326.

[56] Peterson GI and Masel J. Quantitative prediction of molecular clock and $K a / K s$ at short timescales, Molecular Biology and Evolution, 2009; doi:10.1093/molbev/msp175.

[57] Öztürk PN and Çiplak B. Phylomitogenomics of Phaneropteridae (Orthoptera): Combined data indicate a poorly conserved mitogenome. International Journal of Biological Macromolecules. 2019; 
doi:10.1016/jijbiomac.2019.4.011.

[58] Dowton M, Cameron SL, Dowavic JI, Austin AD, Whiting MF. Characterization of 67 mitochondrial tRNA gene rearrangements in the Hymenoptera suggests that mitochondrial tRNA gene position is selectively neutral. Molecular Biology and Evolution. 2009; doi:10.1093/molbev/msp072.

[59] Piekarski PK, Carpenter JM, Lemmon AR, Lemmon EM, Sharanowski BJ. Phylogenomic evidence overturns current conceptions social evolution in wasps (Vespidae). Molecular Biology and Evolution. 2018; doi:10.1093/molbev/msy124.

[60] Pickett KM and Wenzel JW. Phylogenetic analysis of the New World Polistes (Hymenoptera: Vespidae: Polistinae) using morphology and molecules. Journal of the Kansas Entomological Society. 2004; doi:10.1046/j.1365-3113.2000.00102.x.

[61] Kim JS, Jeong JS, Su YJ. Complete mitochondrial genome of the black-tailed hornet, Vespa ducalis (Hymenoptera: Vespidae): genomic comparisons in Vespoidea: complete mitochondrial genome of Vespa ducalis. Entomological Research. 2017; doi:10.1111/1748-5967.12218.

[62] Huang P, Carpenter JM, Chen B, Li TJ. The first divergence time estimation of the subfamily Stenogastrinae (Hymenoptera: Vespidae) based on mitochondrial phylogenomics. International Journal of Biological Macromolecules. 2019; doi:10.1016/j.ijbiomac.2019.06.239.

[63] Bailey W. Principles of paleogeography. Science. 1910; 31(790): 241-260.

[64] van der Vecht, J. The geographical distribution of the social wasps (Hymenoptera, Vespidae). Proceedings of the $12^{\text {th }}$ International Congress on Entomology. 1965; 440-441.

[65] Santos BF, Paynea A, Pickett KM, Carpenter JM. Phylogeny and historical biogeography of the paper wasp genus Polistes (Hymenoptera: Vespidae): implications for the overwintering hypothesis of social evolution. Cladistics, 2014; doi:10.1111/cla.12103.

[66] Scotese CR. A continental drift flipbook. Geological Journal. 2004; doi:10.1086/424867.

[67] de Oliveira FB, Molina EC, Marroig G. Paleogeography of the South Atlantic: a route for primates and rodents into the New World? Garber, P.A. et al. (eds.), South American Primates, developments in primatology: progress and prospects. 2009; doi:10.1007/978-0-387-78705-33.

[68] Jin SG and Zhu WY. Discussion the newest global plate motion model ITRF2000VEL. Geophys. 2002; doi:10.1080/12265080208422884.

[69] Sclater JG. The paleobathymetry of the Atlantic Ocean from the Jurassic to the present. Journal of Geology. 1977; doi:10.2307/30059117. 
[70] Ford D and Golonka J. Phanerozoic paleogeography, paleoenvironment and lithofacies maps of the circum-Atlantic margins. Marine and Petroleum Geology. 2003; doi:10.1016/S0264-8172(03)00041-2.

[71] Wright NM, Seton M, Williams SE. The Late Cretaceous to recent tectonic history of the Pacific Ocean basin. Earth Science Reviews. 2016; doi:10.1016/jearscirev.2015.11.015.

[72] Seton M, Flament N, Whittaker J. Ridge subduction sparked reorganization of the Pacific plate-mantle system 60-50 million years ago. Geophysical Research Letters, 2015; 42(6), 1732-1740.

[73] Gasperini L, Bernoulli D, Bonatti E, Borsetti AM, Ligi M, Sartori NAR, von Salis K. Lower Cretaceous to Eocene sedimentary transverse ridge at the Romanche Fracture Zone and the opening of the equatorial Atlantic. Marine and Petroleum Geology. 2001; doi:10.1016/S0025-3227(01)00146-3.

[74] Heydolph K, Murphy DT, Geldmacher J. Plume versus plate origin for the Shatsky Rise oceanic plateau (NW Pacific): insights from Nd, Pb and Hf isotopes. Lithos, 2014; 200/201, 49-63.

[75] Hilde TWC, Uyeda S, Kroenke L, 1977 Evolution of the western Pacific and its margin. Tectonophysics, 1977; doi:10.1016/0040-1951(77)90205-0.

[76] Sanmartı ' $n$ I and Ronquist F. Southern hemisphere biogeography inferred by event-based models: plant versus animal patterns. Systems Biology. 2004; doi:10.1080/10635150490423430.

[77] Saito F and Kojima J. Taxonomy and biogeography of Australian species of the Ropalidia stigma group and $R$. variegata group (Hymenoptera: Vespidae). Entomological Science 2005; doi:10.1111/j.1479-8298.2005.00111x.

[78] Hill JK, Griffiths HM, Thomas CD. Climate change and evolutionary adaptations at species range margins. Annual Review of Entomology. 2011; doi:10.1146/annurev-ento-120709-144746.

[79] Louis M, Skovrind M, Castruita JAS, Garilao C, Kaschner K, Gopalakrishnan K, Haile JS. Lydersen C, Kovacs KM, Garde E, Heide-Jørgensen MP, Postma L, Ferguson SH, Willerslev K, Lorenzen ED. Influence of past climate change on phylogeography and demographic history of narwhals, Monodon monoceros. The Royal Society. 2020; doi:10.1098/rspb.2019.2964.

[80] Cui ZJ, Chen YX, Zhang W. Research history, glacial chronology and origins of Quaternary glaciations in China. Quaternary Sciences. 2011; 31(5), 749-764.

[81] Shi YF. Characteristics of late Quaternary monsoon glaciation on the Tibetan Plateau and in East Asia. Quaternary International. 2002; doi:10.1016/S1040-6182(02)00053-8.

[82] Yang JQ, Zhang W, Cui ZJ. Late Pleistocene glaciation of the Diancang and Gongwang Mountains, southeast margin of the Tibetan Plateau. Quaternary International, 2006;

doi:10.1016/jquaint.2006.02.003. 
[83] Miryam BM, Avner A. Late Quaternary Paleoclimate in the Eastern. Mediterranean region from stable Isotope analysis of Speleothems at Soreq Cave, Israel. Quaternary Research. 1997; 47, 155 -168.

[84] Ye XZ, Zhao GH, Zhang MZ, Cui XY, Fan HH, Liu B. Distribution pattern of endangered plant Semiliquidambar cathayensis (Hamamelidaceae) in response to climate change after the last Interglacial Period. Forests. 2020; doi:10.3390/f11040434.

[85] Green JP, Rose C, Field J. The role of climatic factors in the expression of an intrasexual signal in the paper wasp Polistes dominulus. Ethology. 2012; doi :10.1111/j.1439-0310.2012.02067x.

[86] Elisei T, Guimaraes DL, Ribeiro C, Melo AC, Grazinoli DJ, Lopes JFS, Prezoto F. Influence of environmental factors on the foraging activity of the paper wasp Polistes simillimus (Hymenoptera, Vespidae). Sociobiology. 2008; doi:10.1021/ba-1968-0076.ch037.

[87] José VAF, Danielle ST, Ricardo JDS, Alexandre S, Mônica JBP, Dionei JDS. Effect of habitat amount and complexity on social wasps (Vespidae: Polistinae): implications for biological control. Journal of Insect Conservation. 2020; doi:10.1007/s10841-020-00221-7.

[88] Jun SY, Kim JH, Choi J, Kim SJ, Kim BM, An SI. The internal origin of the west-east asymmetry of Antarctic climate change. Science Advances. 2020; doi:10.1126/sciadvaaz1490.

[89] Hof AR, Svahlin A. The potential effect of climate change on the geographical distribution of insect pest species in the Swedish boreal forest. Scandinavian Journal of Forest Research. 2015; doi:10.1080/02827581.2015.1079644.

[90] Degani G. The habitats, burrowing behavior, physiology adaptation and life cycle of Spadefoot Toads (Pelobates syriacus Boettger, 1869) at the southern limit of its distribution in Israel. Open Journal of Animal Sciences. , 2015; doi:10.4236/ojas.2015.53029.

[91] Hallman GJ, Denlinger DL. 1998 Temperature sensitivity in insects and application in integrated pest management. Oxford: Westview Press. 7-55. (doi:10.1201/9780429308581)

[92] Ibanez T, Keppel G, Menkes C, Gillespie TW, Lengaigne M, Mangeas M, Rivas-Torres G, Birnbaum P. Globally consistent impact of tropical cyclones on the structure of tropical and subtropical forests. Journal of Ecology. 2019; doi:10.1111/1365-2745.13039.

[93] Ojo JS, Owolawi PA. Characterization of rain heights due to $0^{\circ} \mathrm{C}$ isotherm in tropical and subtropical climates: implication on rain-induced attenuation prediction. Springer Vienna. 2019; doi:10.1007/s00704018-2382-z.

[94] Zhan F, Yu DY, Luo YZ, Ho SYW, Wang BX and Zhu CD. Cryptic diversity, diversification and vicariance in two species complexes of Tomocerus (Collembola, Tomoceridae) from China. Zoologica Scripta. 2013; doi:10.1111/zsc.12056. 


\section{Supplementary Material}

Table. S1 Collection information of seventeen newly sequenced specimens.

Table. S2 The information of mitochondrial genomes in this study.

Fig. S1 Mitochondrial genomes of Polistes, Ropalidia and Parapolybia sequenced in this study. (In consideration of the almost consistent mitochondrial structure within genus, one inner circle of each genus was only presented in this paper.)

Fig. S2 Mtgenome organization of Polistes, Parapolybia and Ropalidia referenced with the ancestral insect mtgenomes. The underlined symbols are located on the $\mathrm{N}$-strand and others on the J-strand. The yellow, blue and green blocks denote tRNAs, PCGs and control regions, respectively. The red font means rearranged genes.

Fig. S3 The A+T content (\%), AT-skew, G+C content (\%) and GC-skew of the Polistes, Ropalidia and Parapolybia whole mitogenomes.

Fig. S4 Mitochondrial gene rearrangements in Polistes, Parapolybia and Ropalidia. Genes are transcribed from left to right except those underlined, which have the opposite transcriptional orientation. The yellow, blue, purple and gray blocks denote tRNAs, PCGs, IGS and Random loss gene, respectively. IGS for the intergenic spacer.

Fig. S5 Reconstruction of phylogenetic tree determined by Bayesian inference and Maximum Likelihood methods based on PCGR and AA datasets of Vespidae mtgenomes. Bayesian posterior probabilities (left) and Parsimony bootstrap (right) are shown at relevant branches of the ML tree.

\section{Figures}



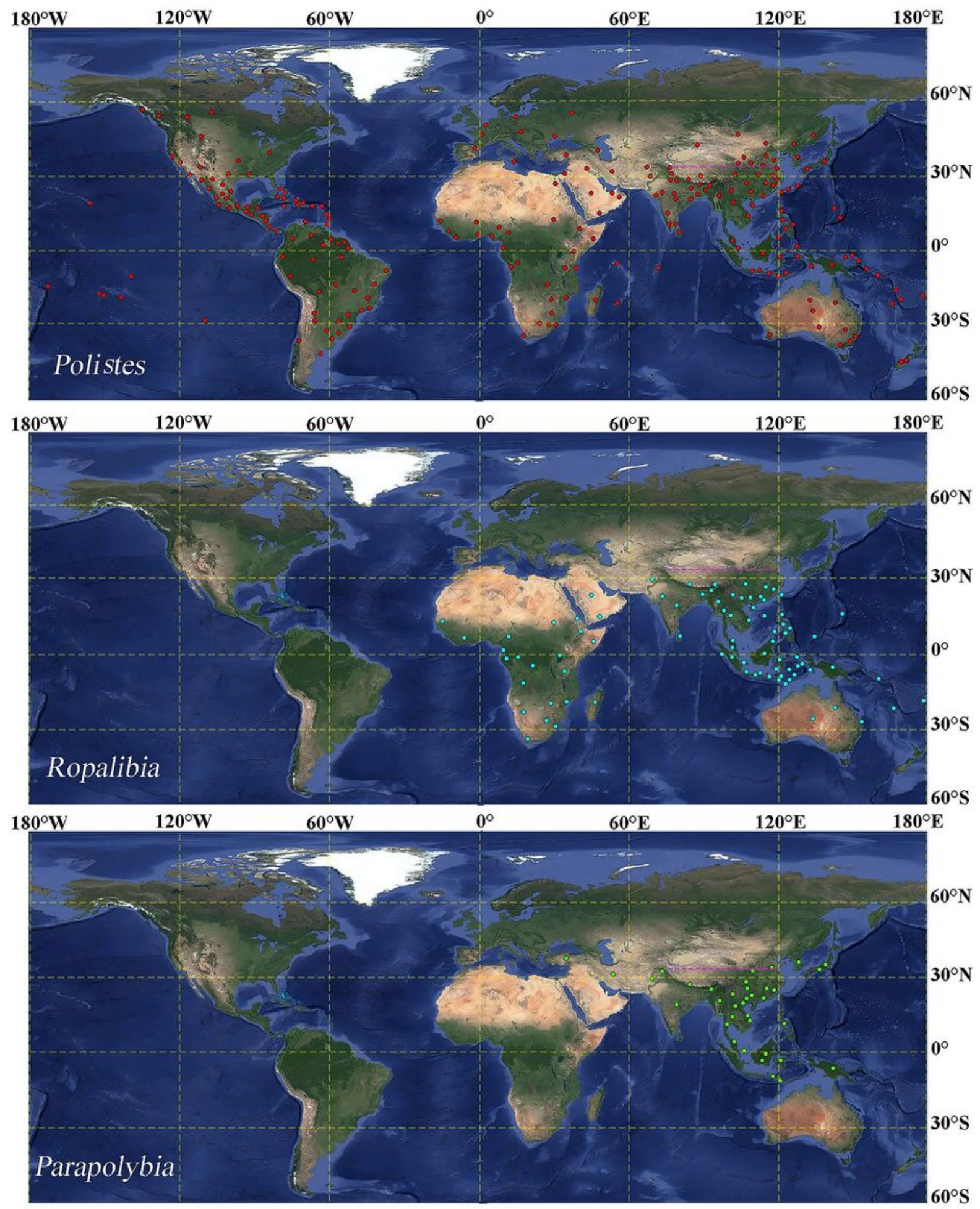

QH line

\section{Figure 1}

Distributions of Polistes, Ropalidia, and Parapolybia. The purple dashed line represents Qinling Mountains-Huai River (QH) line, and the dots in red, blue, and green represent the recorded distribution locations of Polistes, Ropalidia, and Parapolybia, respectively. Note: The designations employed and the presentation of the material on this map do not imply the expression of any opinion whatsoever on the part of Research Square concerning the legal status of any country, territory, city or area or of its 
authorities, or concerning the delimitation of its frontiers or boundaries. This map has been provided by the authors.
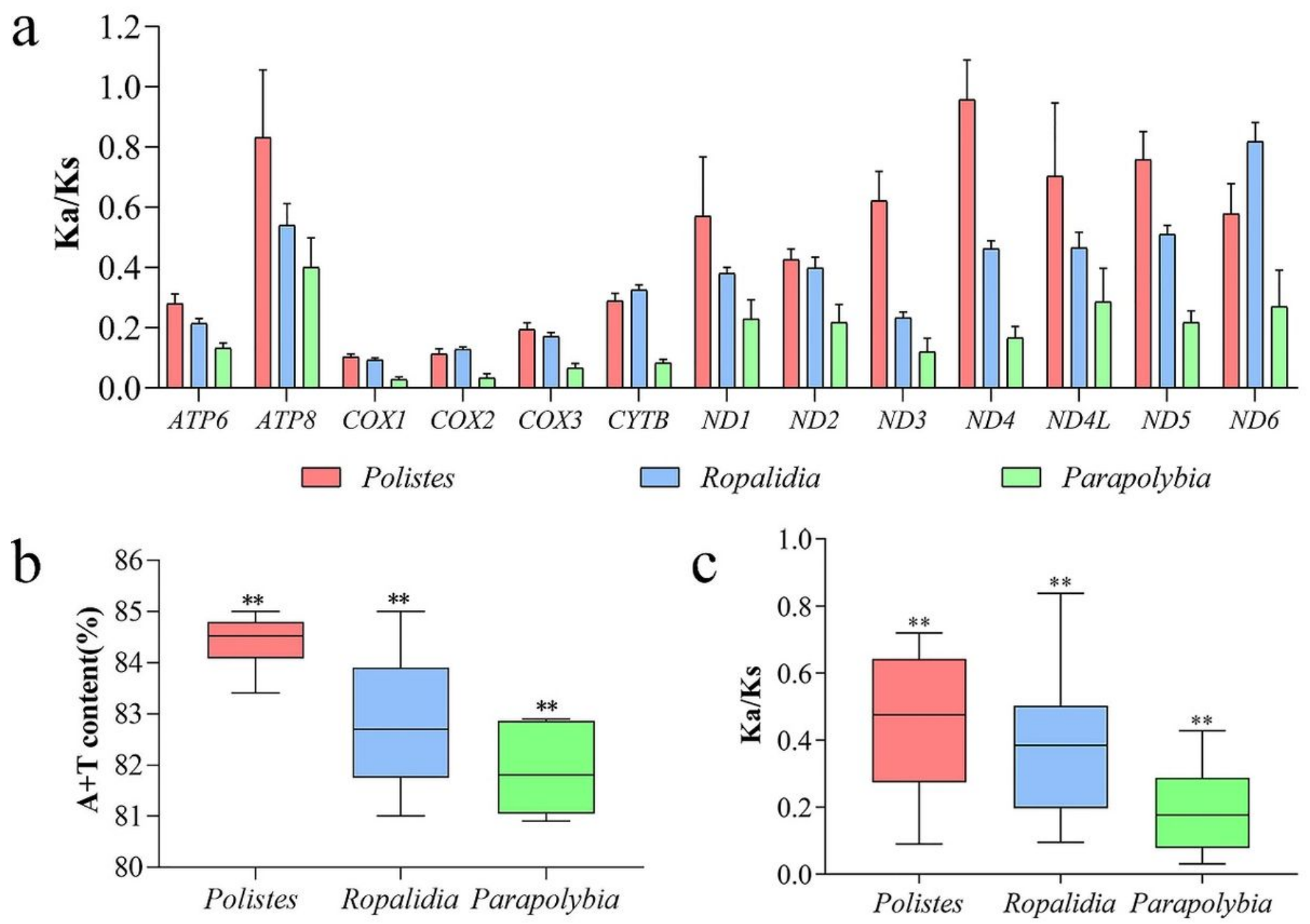

Polistes

Ropalidia

\section{Parapolybia}

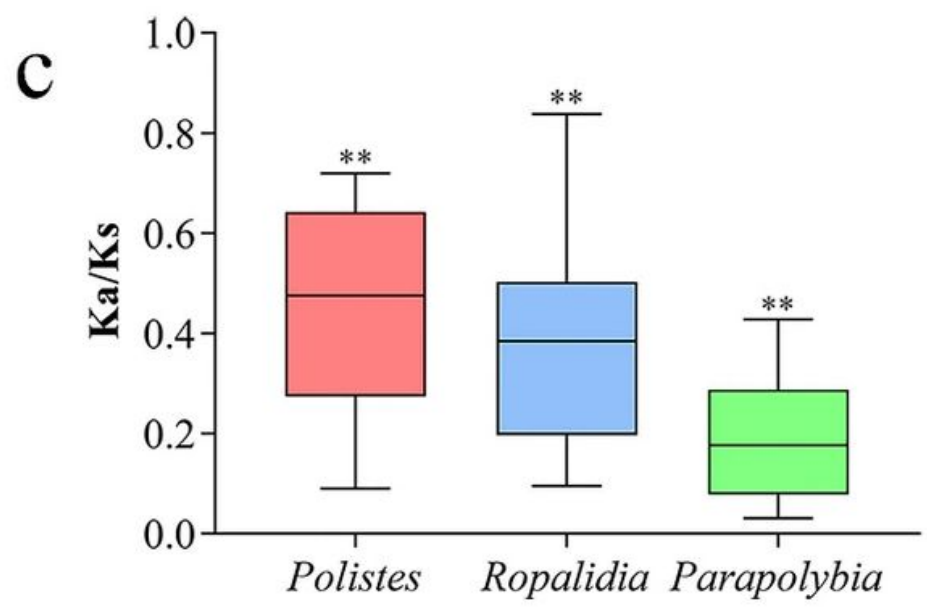

Figure 2

a: The Ka/Ks values of Polistes, Ropalidia and Parapolybia for 13 PCGs, respectively; b: The A+T content (\%) of Polistes, Ropalidia and Parapolybia with whole mitogenomes, $* *$ : $\mathrm{P}<0.01$; c: The Ka/Ks values of Polistes, Ropalidia and Parapolybia for total PCGs, ,*: P<0.01. 


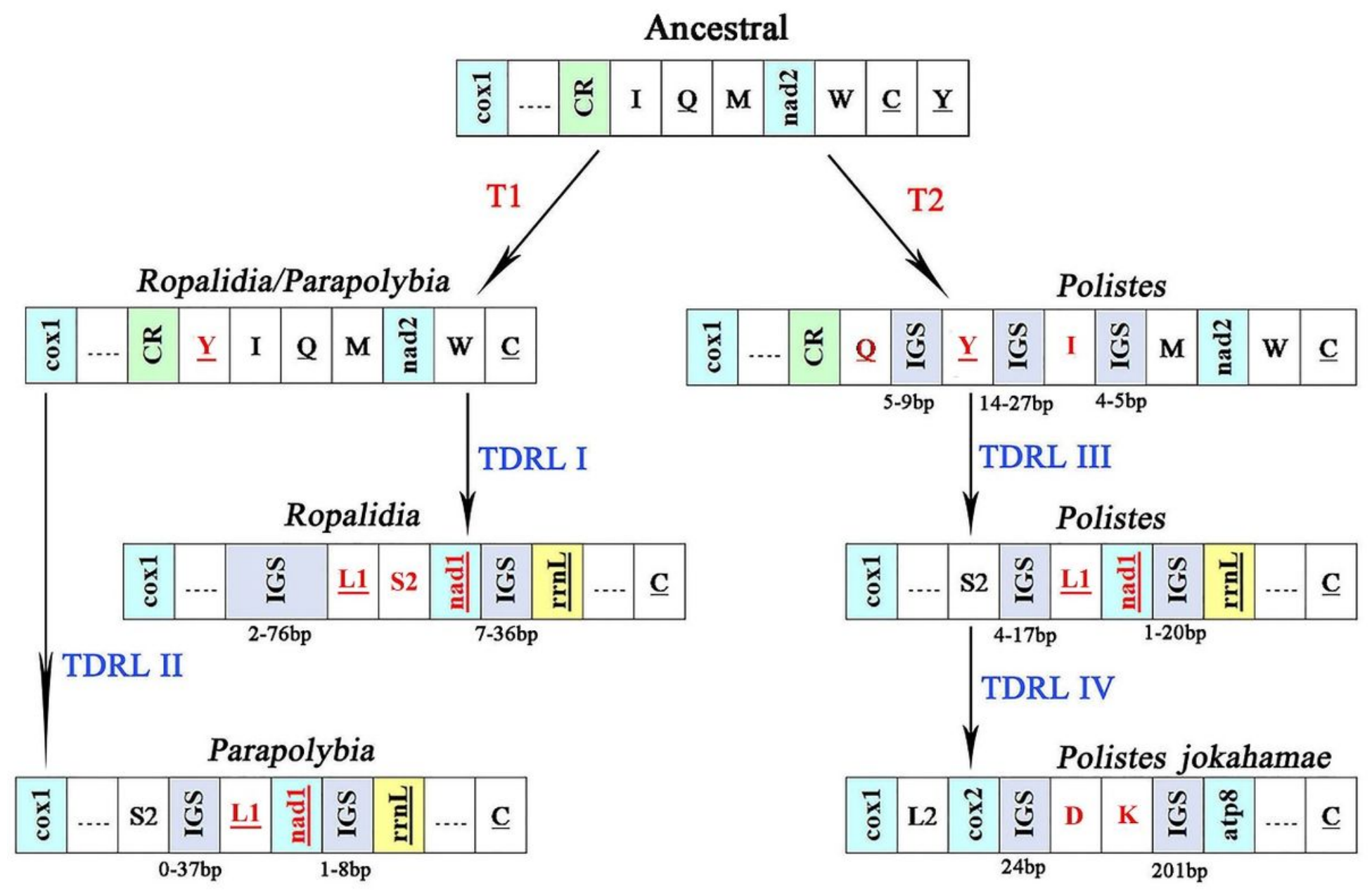

Figure 3

Mitochondrial gene rearrangements in Polistes, Parapolybia and Ropalidia. IGS for the intergenic spacer, TDRL for tandem-duplication-random-loss, $T$ for translocation. 


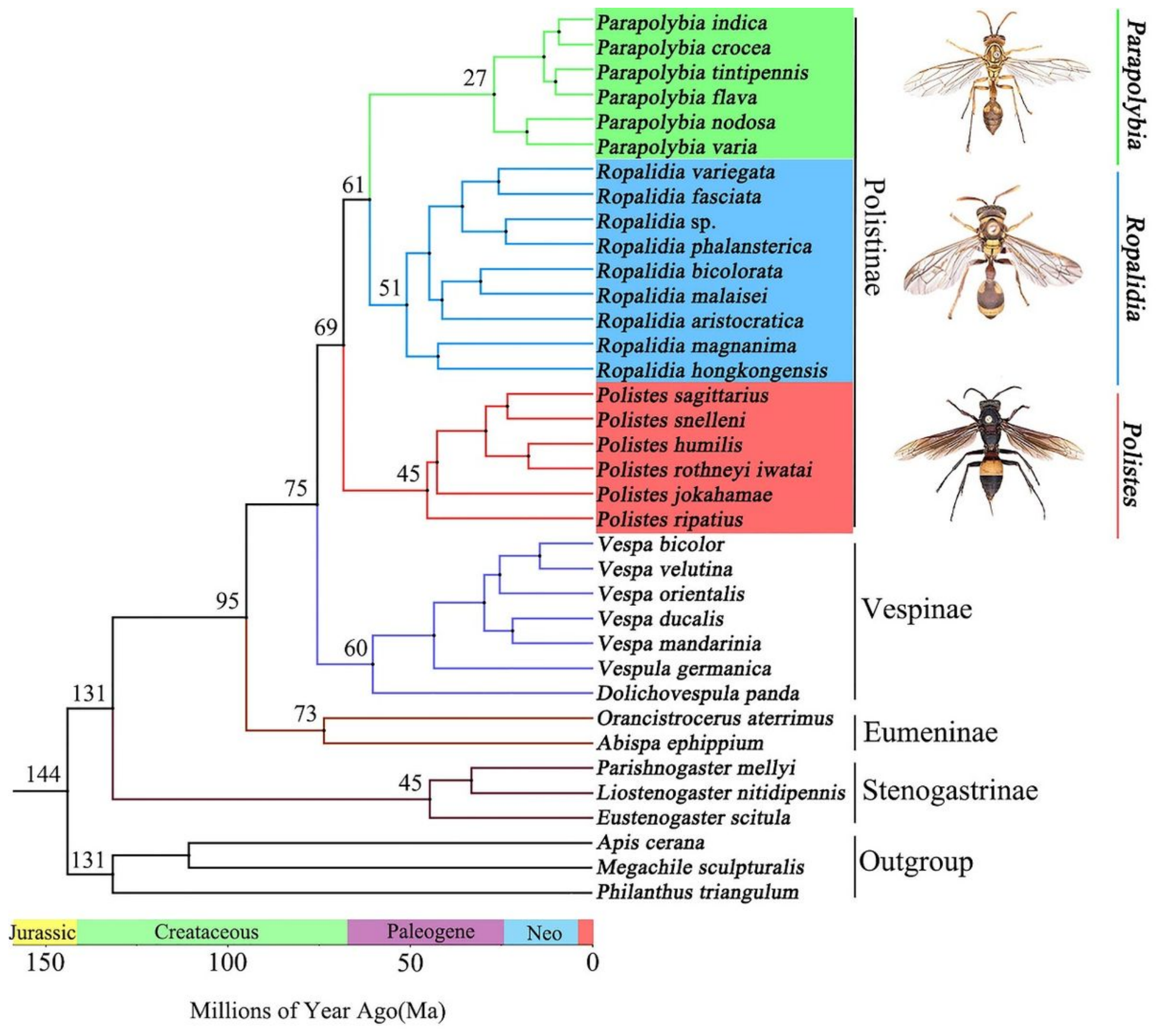

Figure 4

Evolutionary timescale for Polistes, Parapolybia and Ropalidia inferred from PCGR dataset. 


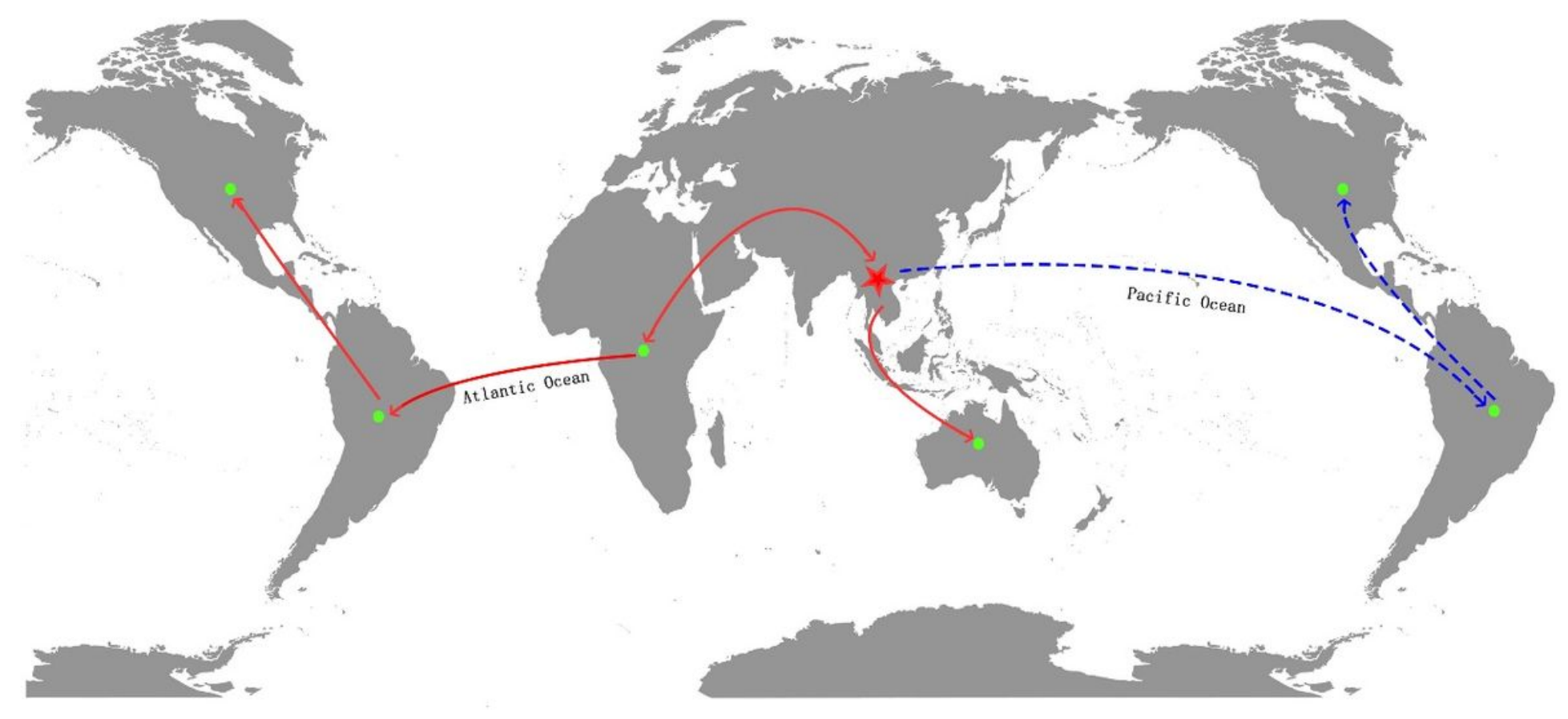

Figure 5

The proliferation route of Polistes from the Old World to the New World. Southeast Asia as the ancestor region of Polistes in New World is marked by a star. Transatlantic routes of invasion are shown in solid red line, potential transpacific routes of invasion are shown in blue dashes. The green dot only represents its continent rather than any specific location. Note: The designations employed and the presentation of the material on this map do not imply the expression of any opinion whatsoever on the part of Research Square concerning the legal status of any country, territory, city or area or of its authorities, or concerning the delimitation of its frontiers or boundaries. This map has been provided by the authors.

\section{Supplementary Files}

This is a list of supplementary files associated with this preprint. Click to download.

- Electronicsupplementarymaterial.doc 